\title{
Can fish introductions alter nutrient cycles in previously fishless high-latitude lakes?
}

\author{
Marco MILARDI, ${ }^{1 *}$ Jyrki LAPPALAINEN, ${ }^{1}$ Suzanne MCGOWAN, ${ }^{2,3}$ Jan WECKSTRÖM ${ }^{1}$ \\ ${ }^{1}$ Department of Environmental Sciences, University of Helsinki, P.O. Box 65, 00014 Helsinki, Finland; ${ }^{2}$ School of Geography, \\ University of Nottingham Malaysia Campus, Jalan Broga, 43500 Semenyih, Selangor Darul Ehsan, Malaysia; ${ }^{3}$ School of Geography, \\ University of Nottingham, University Park, Nottingham NG7 2RD, UK \\ *Corresponding author: marco.milardi@helcom.fi
}

\begin{abstract}
The additional input and enhanced cycling of nutrients derived from introduced fish can be a significant factor altering nutrient dynamics in oligotrophic lakes. To test this, we used a bioenergetic model to estimate the fish-derived nutrient load in Lake Kuntsjärvi, a historically fishless boreal lake of northern Fennoscandia. The lake was selected because of the absence of other anthropogenic stressors, a known stocking history and the possibility of quantitatively estimating the size-structure and biomass of the fish population through a mass removal. Subsequently, we used a mass balance model to compare fish-derived nutrients with other nutrient load pathways. For comparison over longer timescales, we used lake sediment records of diatoms, chlorophyll and carotenoid pigments, C:N ratios and stable isotopes to infer whether fish introduction produced detectable changes in the lake trophic state, primary productivity and terrestrial nutrient input. Based on the nutrient mass balance model, we found that phosphorus and nitrogen derived from fish were $0.46 \%$ and $2.2 \%$, respectively, of the total load to the lake, suggesting that fish introduction could not markedly increase the nutrient load. Accordingly, the palaeolimnological record indicated little increase in primary production but instead a shift from pelagic to benthic production after fish introduction.
\end{abstract}

Key words: Nutrient cycle; bioenergetic model; fish introduction; chlorophyll and carotenoid pigments; diatoms; stable isotopes.

Received: October 2015. Accepted: March 2016.

\section{INTRODUCTION}

Nutrient cycling between water, sediment and biota is the movement and exchange of organic and inorganic compounds between the environment and the living matter. Over long term (centennial-millenial) timescales, nutrient cycles in high-latitude lakes are influenced by temperature, atmospheric deposition and hydrography of the catchment area (Kernan et al., 2010). On a shorter term, other anthropogenic factors could be more relevant, ranging from forestry management (Ahtiainen and Huttunen, 1999) to fish introductions (Moss et al., 2003).

Unlike other clades, where introductions are often unintentional, fish introductions are commonly linked to deliberate sport fisheries manipulations (García-Berthou et $a l ., 2005)$. Introduced fish can directly modify habitats (Dibble and Kovalenko, 2009; Weber and Brown, 2009), and alter the food webs of the host ecosystem through trophic cascades (Carpenter et al., 1985; Pace et al., 1999; Strock et al., 2013). Trophic cascades can modify the abundance and trophic relation of several elements of the food web, which can influence the way these elements exploit nutrients and ultimately affect the trophic status of water bodies. Experimental and survey studies have shown that fish introductions may change lake nutrient regeneration markedly (Vanni, 1996; Schindler et al.,
2001) or more subtly (Schindler and Eby, 1997; Pace et al., 2004; Cole et al., 2006; Carpenter et al., 2011) but each highlighted the important role of fish in transporting nutrients between benthic and pelagic zone or between terrestrial and aquatic environments. Fish predation can move and transform nutrients derived from benthic or terrestrial prey to a bioavailable excretion in the pelagic areas of lakes, resulting in a net regeneration of nutrients. However, isolating the effects of fish introductions on the trophic state of lakes from other concurrent pressures remains challenging (Gąsiorowski and Sienkiewicz, 2013).

Fish are generally highly linked with several levels of the food web (Duffy et al., 2007) due to their complex trophic interactions (Dunne et al., 2002). This complexity of trophic linkages increases ecosystem resilience, but also the difficulties to track specific changes in lakes where fish are already present (Folke et al., 2004). Therefore, fish introductions should have the greatest impact in previously fishless lakes (Schindler et al., 2001).

Most small lakes in Fennoscandia were fishless for a long period after the last deglaciation, but fish were intentionally introduced to many of them in recent centuries (Tammi et al., 2003). While some studies exist on the food web changes induced by introduced fish in Fennoscandia (Bøhn and Amundsen, 2001; Hayden et al., 2013), none have focused on the consequences on nutrient cycling. 
Palaeolimnological analyses (i.e. the study of subfossil and physicochemical characteristics of lake sediment cores) can be used to reconstruct past trophic and production changes through subfossil proxies of primary producers (Battarbee, 2000) as well as changes in coupling with the terrestrial ecosystems through stable isotope analysis (McLauchlan et al., 2013). Therefore, palaeolimnology can be used to infer changes in nutrient cycling through changes in primary production, if the dates of fish introduction are known or can be estimated. However, few studies have yet used a palaeolimnological approach to examine this question (Leavitt et al., 1994).

We hypothesized that fish introductions have been significant in altering the nutrient balance of small high-latitude lakes. To test this hypothesis, we selected a small lake in northern Fennoscandia, with a known fish stocking history, isolated from other local anthropogenic stressors, and sufficiently shallow to enable the removal of the whole fish population. We used complete fish removal as a unique opportunity to quantitatively estimate the fish biomass, an essential parameter in nutrient dynamics models. We employed a bioenergetic model to evaluate the magnitude of nutrient cycling effects derived from introduced brown trout (Salmo trutta L.). Fish-derived nutrient loads were then compared with other nutrient sources in a comprehensive lake nutrient budget. The model was also used to test whether fish act as a net source or sink of nutrients. Taking advantage of the welldocumented disturbance history of the lake, we sought to validate our findings from the bioenergetic model and investigate how lake production responded to fish introduction and removal, over longer timescales. Therefore, we analysed diatom, chlorophyll and carotenoid pigments, and stable isotopes of carbon $\left(\delta^{13} \mathrm{C}\right)$ and nitrogen $\left(\delta^{15} \mathrm{~N}\right)$ in sediment cores as proxies to test for changes in lake primary production and the input of terrestrial matter. In particular, we expected that diatom and algal communities would respond to changes in nutrient availability due to trout excretion, increasing the abundance of nutrient-sensitive species (e.g. Asterionella formosa). Furthermore, we expected that stable isotopes in the sediment would record more terrestrial matter (i.e., a depletion in $\delta^{13} \mathrm{C}$ ratios) if trout predation on terrestrial prey had created a new alternative pathway of nutrient transport.

\section{METHODS}

\section{Study site}

Lake Kuutsjärvi $\left(67^{\circ} 44^{\prime} 49.13^{\prime \prime} \mathrm{N}, 2^{\circ} 36^{\prime} 35.47^{\prime \prime} \mathrm{E}\right)$ is a small (circa $0.7 \mathrm{ha}$ ) north-boreal headwater lake, located at an altitude of $341 \mathrm{~m}$ above mean sea level, in northeastern Finnish Lapland (Fig. 1). Water temperatures, measured at $2 \mathrm{~m}$ of depth during 2009-2012, vary from a minimum of $1.5^{\circ} \mathrm{C}$ in January to a maximum of $11.8^{\circ} \mathrm{C}$ in July. The ice-free period typically lasts from late May to early October. The lake is mesotrophic (TP 13-26 $\mu \mathrm{g} \mathrm{L}^{-1}$, TN $67-152 \mu \mathrm{g} \mathrm{L}^{-1}$ ) and shallow with clear water (max depth $8.5 \mathrm{~m}$, Secchi depth to the bottom). The catchment area is small $\left(<1.5 \mathrm{~km}^{2}\right)$, with steep slopes surrounding the lake covered by north-boreal coniferous forest dominated by Scots pine (Pinus sylvestris), but the upper part of the catchment area is treeless tundra. The lake was originally fishless due to migration barriers (waterfalls, rocks and steep rapids) in its small outlet brook. However, in 1980 it was stocked with adult brown trout (hereafter trout) from nearby populations (E. Pulliainen, personal communication) to create local recreational fisheries. The

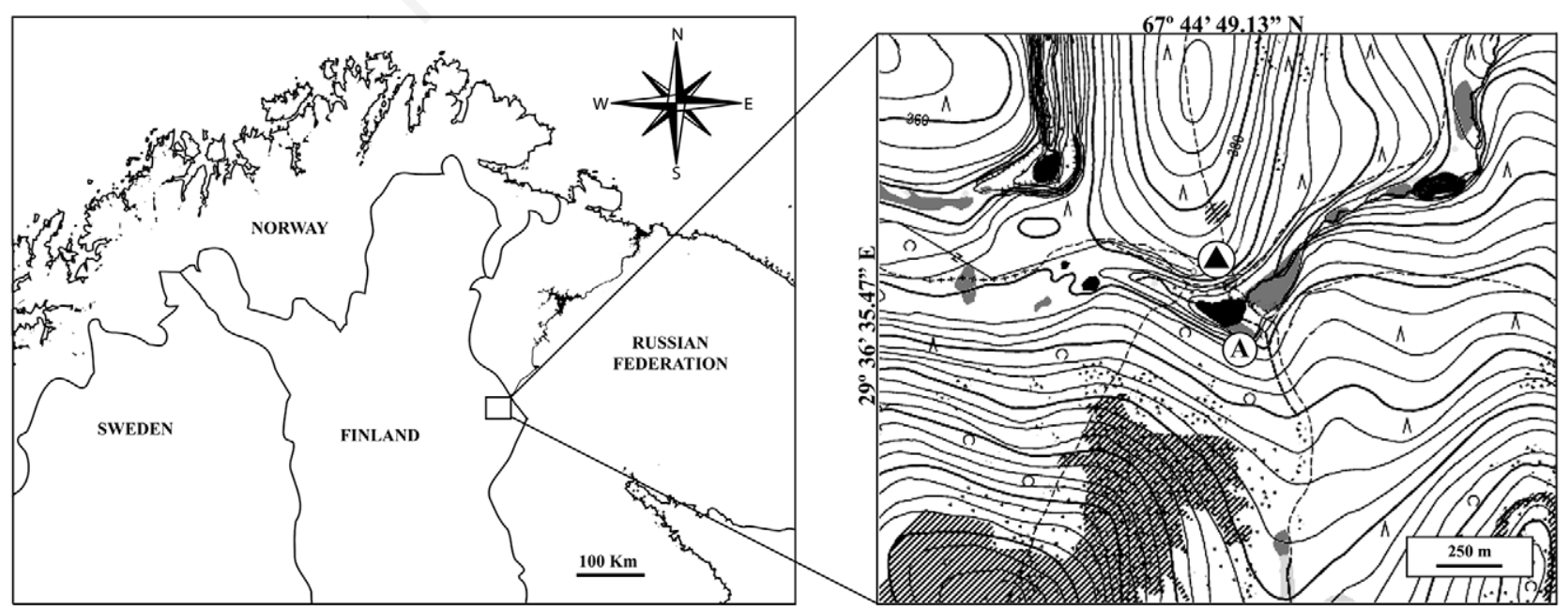

Fig. 1. Map of the study area showing its location in northern Fennoscandia, Lake Kuutsjärvi (A) and the Värriö Research Station ( $\mathbf{\Delta})$. 
trout quickly established a self-sustaining population that reproduces in the lake. A small outlet, blocked with a metal grill, allowed the water to flow out of the lake but enclosed the introduced fish. In 1981, the Värriö Natural Reserve was officially established, comprising an area of $125 \mathrm{~km}^{2}$ roughly centred around Lake Kuutsjärvi and the nearby research station. Värriö Natural Reserve is a strict natural reserve and no human activities, other than research, are allowed in the area.

\section{Fish sampling and bioenergetic model}

Trout were removed from Lake Kuutsjärvi between 2010 and 2012. Fish were mainly captured using multimesh gillnets (mesh sizes of 10-60 mm, knot to knot), rodand-line and a baited longline, during sampling events at the beginning of June, July and August. Over $90 \%$ of the total individuals were caught already in August 2011 and fishing continued in 2012 when the last few individuals were captured. Given the high fishing effort concentrated in a small lake, fish removal was discontinued when catch per unit of effort declined to 0 for more than one week and the population was considered removed. Specimens were immediately sacrificed by head concussion and frozen at the Värriö Research Station, located in the immediate vicinity of the lake (Fig. 1). Subsequently, samples were thawed and the total length of fish was measured with a precision of $1 \mathrm{~mm}$ and weighed with a precision of $0.1 \mathrm{~g}$. Stomach contents analysis (SCA) was performed using a volumetric point method (Windell, 1971), in which stomach fullness was visually estimated using a scale from 0 (empty) to 10 (full) and the relative proportion of each prey item to total stomach fullness was estimated. Each prey item was identified as accurately as possible to genus, family or sub-order level. Subsequently, the total volumes of prey items were pooled into five larger categories, which were terrestrial arthropods, aquatic arthropods, rodents, amphibians and indigestible content (detritus), to be used in the bioenergetic model.

The Monastyrsky formula was used to back-calculate size-at-age from scale rings and to reconstruct growth increments for years when direct measures at age were not available (Bagenal and Tesch, 1971). Weights were estimated based on a length/weight exponential equation (1):

$W=a \times L^{b}$

where $\mathrm{W}$ is weight $(\mathrm{g}), \mathrm{L}$ is total length $(\mathrm{cm})$ and parameters $a$ and $b$ were fitted on the distribution of lengths and weights of the whole population. To confirm age readings obtained from scales, sagittal otoliths of the sampled trout were also collected, stained with alizarin red $\mathrm{S}$ and examined under a stereomicroscope. If age readings differed, otolith readings were considered to be more reliable (Thaulow et al., 2017). Visual inspection of gonads was carried out to assess maturity of individuals and sex ratio of the population.

A bioenergetic model was used to estimate nutrient regeneration rates of trout. The model estimated consumption rates and excretion rates for each cohort in the population (accounting for mortality), based on speciesspecific metabolic levels and measured water temperatures. To compute nutrient consumption and excretion rates, the model used diet proportions derived from SCA, energy/nutrient content for each prey item and average measured growth rates.

Consumption rates were calculated using a temperature-dependent bioenergetic model for cool-water species (2) (Thornton and Lessem, 1978; Hanson et al., 1997):

$C=K A \times K B$

where:

$K A=(C K 1 \times L 1) /(1+C K 1 \times(L 1-1))$;

$L 1=e^{(G 1 \times(T-C Q))}$;

$G 1=(1 /(C T 0 C Q)) \times \ln ((0.98 \times(1-C K 1)) /(C K 1 \times 0.02))$;

$K B=(C K 4 \times L 2) /(1+C K \times(L 2-1)$;

$L 2=e^{(G 2 x / C T L-T))}$;

$G 2=(1 /(C T L-C T M)) \times \ln ((0.98 \times(1-C K 4)) /(C K 4 \times 0.02))$;

Where $\mathrm{C}$ is consumption, $\mathrm{T}$ is temperature, $\mathrm{CA}$ is the intercept of the mass dependence function for a $1 \mathrm{~g}$ fish at the optimum water temperature and $\mathrm{CB}$ is the coefficient of the mass dependence. CQ is the lower water temperature at which the temperature dependence is a small fraction (CK1) or the maximum rate. CT0 is the water temperature corresponding to 0.98 of the maximum consumption rate. CTM is the temperature ( $\geq \mathrm{CT} 0)$ at which dependence is still 0.98 of the maximum and CTL is the temperature is some reduced fraction (CK4) of the maximum rate.

Excretion rates were calculated as a function of consumption, with the expression (3) (Kitchell et al., 1977):

$U=U A x(C-F)$

where UA is a constant proportion of assimilated energy, times consumption (C) minus egestion (F, a constant proportion of consumption).

The bioenergetic model took into account all the different fish cohorts and their respective biomasses, as the different age-classes have different metabolic levels and thus different regeneration rates. Population parameters were reconstructed for 2009, before sampling began, and were used to model the population in undisturbed conditions. Species-specific parameters were derived from values reported in Dieterman et al. (2004) for stream dwelling populations of trout. Temperatures were continuously recorded at different depths with HOBO water temperature data loggers throughout the study period (2009-2012). In the bioenergetic model, daily tempera- 
tures, recorded at 12:00 at a depth of $2 \mathrm{~m}$ throughout year 2009 , were used to estimate the feeding activity of trout. This is the depth of the littoral zone, a preferred depth for trout activity (since trout are often littoral and surface-oriented predators) and at this depth temperatures are less susceptible to small-scale daily variations.

As different prey has variable energy and nutrient contents, they are processed differently by the fish metabolism. Therefore, stomach content data were used to define prey proportions in the model (Tab. 1) in order to derive specific assimilation and excretion rates. Energy contents of specific prey items and trout were derived from direct calorimetric measures by Cummins and Wuycheck (1971). Detritus (i.e., plant matter) was considered to be non-energetic. Values of $\mathrm{N}$ content in trout muscle and their prey were directly measured in samples from the lake food web with an elemental analyser (TruSpec Micro, LECO Corporation, St. Joseph, Michigan, U.S.A.). Phosphorus $(\mathrm{P})$ concentration in prey and trout was derived from Penczak et al. (1985), Nakashima and Leggett (1980), Elser et al. (2000) and Dierenfeld et al. (2002). An assimilation coefficient of 0.72 for the uptake of both nutrients ( $\mathrm{N}$ and $\mathrm{P}$ ) was used (Nakashima and Leggett, 1980). Consumption of all terrestrial prey items was set to 0 during ice-cover, as they would be inaccessible. The remaining proportion of the diet was assumed to shift towards a purely aquatic diet (Tab. 1). The model also accounted for annual population dynamics, with an average $10 \%$ weight loss at spawning, due to the release of gametes (Jonsson and Jonsson, 1999) and 10\% natural mortality for all mature cohorts (Jonsson and Jonsson, 2011).

Nutrient load in trout excretion was estimated through a function of the bioenergetic model that takes into account specific nutrient content of both consumed prey and trout (Kraft, 1992). N and P not assimilated by trout (egested in faeces) would not be immediately available to phytoplankton. In contrast, assimilated nutrients subsequently evacuated (excreted in urine) were assumed to be directly available to primary producers and to contribute to internal load (Brabrand et al., 1990; Lall, 1991).

To assess the extent of trout being either a sink or a generator of nutrients we compared the amount of nutrients segregated into fish bodies (sink) versus the amount of nutrients regenerated via excretion (generation). The wet mass composition of nutrients in fish bodies was calculated based on the population biomass of 2009, as used in the bioenergetic model, and accounting for mortality rates. Both the annual biomass gain and the total biomass were compared with nutrient regeneration rates.

\section{Nutrient mass balance model}

Internal and external nutrient loadings were calculated on an annual basis and year 2009, before the sampling began, was taken as a model year for calculations. We assumed that the main factor affecting the internal load of the lake would be fish-derived nutrients. This was supported by the negligible re-suspension of the sediment due to short fetch, the presence of a thick bryophyte mat covering the lake bottom and high depth-to-surface ratio of the lake. The good oxygenation throughout the water column at most times of the year (Milardi, unpublished data) suggests a minimal nutrient re-dissolution. In addition, the well-established sediment chronology suggests a stable and undisturbed sedimentation environment.

We assumed that the external load would derive from the catchment area and the atmospheric load, as there are no other significant external sources of nutrients in the area. Catchment and lake areas were calculated using a polygonal approximation in Arc-GIS. Catchment nutrient load of $\mathrm{P}$ and $\mathrm{N}$ was then estimated on a surface-unit basis, taking into account that most of the catchment area consists of unmanaged forest. Values of $110 \mathrm{~kg} \mathrm{~km}^{-2}$ year ${ }^{-1}$ for $\mathrm{N}$ and 4.2 $\mathrm{kg} \mathrm{km}^{-2}$ year $^{-1}$ for $\mathrm{P}$ were used (Kortelainen et al., 2006). P and $\mathrm{N}$ fallout was estimated from atmospheric deposition measures taken by the Finnish Environmental Centre. Measures were taken on rainwater/snow collected monthly between 2004 and 2012 in Sodankylä (about $130 \mathrm{~km}$ west from Lake Kuutsjärvi). Annual atmospheric average loads

Tab. 1. Prey items and their energy and nutrient content in the diet of trout. Nutrient content is expressed as a proportion of wet weight. Brown trout itself has an energy content of $6247 \mathrm{j} \mathrm{g}^{-1}, \mathrm{~N}$ and $\mathrm{P}$ content of $2.6 \%$ and $0.5 \%$ of wet weight, respectively (f, a). The composition of prey items is expressed as the sum of ingested prey volume across the whole fish population.

\begin{tabular}{|c|c|c|c|c|c|}
\hline \multirow[t]{2}{*}{ Prey item } & \multirow[t]{2}{*}{ Energy content $\left(\mathrm{j} \mathrm{g}^{-1}\right)$} & \multirow[t]{2}{*}{$\mathbf{N}$ content $(\%)$} & \multirow[t]{2}{*}{ P content ( $\%)$} & \multicolumn{2}{|c|}{ Trout diet (\%) } \\
\hline & & & & Open water & Ice cover \\
\hline Terrestrial arthropods & $6000^{\mathrm{a}}$ & $2^{f}$ & $0.3^{\mathrm{c}, \mathrm{d}}$ & $5^{f}$ & $0^{\mathrm{f}}$ \\
\hline Aquatic arthropods & $3000^{\mathrm{a}}$ & $1.7^{\mathrm{f}}$ & $0.17^{\mathrm{b}}$ & $56^{\mathrm{f}}$ & $92.5^{\mathrm{f}}$ \\
\hline Rodents & $13,000^{\mathrm{a}}$ & $2.44^{\mathrm{f}}$ & $1.26^{\mathrm{e}}$ & $31^{f}$ & $0^{f}$ \\
\hline Amphibians & $3800^{\mathrm{a}}$ & $2.17^{\mathrm{f}}$ & $1.4^{\mathrm{e}}$ & $0.5^{\mathrm{f}}$ & $0^{\mathrm{f}}$ \\
\hline Detritus & 0 & 0 & 0 & $7.5^{\mathrm{f}}$ & $7.5^{\mathrm{f}}$ \\
\hline
\end{tabular}

${ }^{a}$ Cummins and Wuycheck, 1971; ${ }^{b}$ Penczak et al., 1985; ${ }^{c}$ Nakashima and Leggett, 1980; ${ }^{d}$ Elser et al., 2000; ${ }^{e}$ Dierenfeld et al., 2002; ${ }^{t}$ this study. 
were estimated to be $3.67 \pm 1.44 \mathrm{~kg} \mathrm{~km}^{-2}$ and $216.89 \pm 38.97$ $\mathrm{kg} \mathrm{km}^{-2}$ of $\mathrm{P}$ and $\mathrm{N}$, respectively. $\mathrm{P}$ and $\mathrm{N}$ atmospheric deposition was assumed to originate from precipitation and dry fallout directly on the lake surface. Internal and external nutrient loadings were then compared to assess the difference in loading with and without fish regeneration.

\section{Palaeolimnological analyses and nutrient model validation}

A HTH-Kajak type gravity corer (Renberg and Hansson, 2008) was used to derive a $19.5 \mathrm{~cm}$ long sediment sequence from the deepest part of Lake Kuutsjärvi in spring 2009. The core was sub-sampled for loss-on-ignition (LOI), radiometric dating, diatoms, and chlorophyll and carotenoid pigment analysis at intervals of $2.5 \mathrm{~mm}$, representing a temporal resolution of ca. 1-10 years. A second core was obtained in spring 2011 and sub-sampled for LOI and stable isotopes of $\mathrm{C}$ and $\mathrm{N}$ at intervals of $5 \mathrm{~mm}$. Both cores were analysed for LOI and sedimentation rate in order to correlate the chronology obtained through radiometric dating. LOI was performed measuring the weight of sediment samples after heating in ceramic cups at $105^{\circ} \mathrm{C}$ overnight and successively igniting at $550^{\circ} \mathrm{C}$ for 4 hs (Heiri et al., 2001).

Sediment samples were analysed for ${ }^{210} \mathrm{~Pb},{ }^{226} \mathrm{Ra}$ and ${ }^{137} \mathrm{Cs}$ by gamma spectrometry in the Environmental Radioactivity Laboratory of Liverpool University. The radiometric dating chronologies were calculated using the Constant Rate of Supply (CRS) dating model (Appleby and Oldfield, 1978). Based on the known low sediment accumulation rates of northern oligotrophic lakes (Korhola and Weckström, 2004) the basal sample for diatom analysis (depth of $19.5 \mathrm{~cm}$ ) was estimated to cover at least the last five hundred years.

Diatoms were prepared using $\mathrm{H}_{2} \mathrm{O}_{2}$ digestion and $\mathrm{HCl}-$ treatment and cleaned diatoms were mounted in Naphrax (Battarbee, 1986). A minimum of 300 diatom valves from each sample were identified and counted along random transects at 1000x magnification. Diatom identification was based mainly on Krammer and Lange-Bertalot (1986, 1988, 1991a, 1991b). For more details concerning the procedure and taxonomic literature used, see Weckström et al. (1997). Counts of 300 specimens per sample were converted into percentages, and these were plotted as a stratigraphical frequency diagram using the program $\mathrm{C} 2$ version 1.72 (Juggins, 2007). In order to identify the periods of time of the most significant shifts in diatom assemblages, the constrained optimal sum of squares partitioning was used to zone the diatom core data (Birks and Gordon, 1985). The number of statistically significant zones was calculated using the broken-stick model and the associated approach described by Bennett (1996). Optimal partitioning was implemented using the program ZONE 1.2 (Lotter and Juggins, 1991).

To quantify past abundance of algal groups, pigments were quantitatively extracted from freeze-dried sediments in acetone: methanol: water $(80: 15: 5)$, filtered $(0.2 \mu \mathrm{m}$ PTFE), dried under nitrogen gas, re-dissolved into acetone, ion-pairing reagent and methanol (70:25:5) and injected into an Agilent 1200 series high performance liquid chromatography (HPLC) system (Leavitt and Hodgson, 2001). Separation conditions were a modification of Chen et al. (2001) using solvent A (80:20 methanol: $0.5 \mathrm{M} \mathrm{am}$ monium acetate), solvent B (9:1 acetonitrile: water) and solvent C (ethyl acetate) with a Thermo Scientific ODS Hypersil column ( $205 \times 4.6 \mathrm{~mm} ; 5 \mu \mathrm{m}$ particle size) for the stationary phase (Thermo Scientific, Bremen, Germany). Pigments were identified based on spectra and retention times, and quantified by calibration with commercial standards (DHI, Denmark). Pigment concentrations are reported as molar weights per unit weight of organic material (estimated by LOI).

Sub-samples for isotopic analysis were ground to a fine powder using a mechanical mortar. To compute the C:N ratio, the masses of $\mathrm{C}$ and $\mathrm{N}$ were determined using an elemental analyser (TruSpec Micro, LECO Corporation, St. Joseph, Michigan, U.S.A.). Samples for C isotopes analysis were weighed and loaded into silver cups, then fumigated for 24 hours under $37 \% \mathrm{HCl}$ vapours to dissolve inorganic C. A minimum of $0.3 \mathrm{mg}$ of sediment was measured for each $\mathrm{C}$ sample. Samples for $\mathrm{N}$ isotope analysis were weighed and loaded into tin cups, then directly analysed. A minimum of $0.4 \mathrm{mg}$ of sediment was measured for each N sample. Sub-samples were analysed using a Finnigan DeltaPlusAdvantage mass spectrometer (Thermo Scientific, Bremen, Germany) connected on-line to an elemental analyser NC 2500 (CE Instruments, Milan, Italy) via a ConFlow III interface (Thermo Scientific, Bremen, Germany). The resulting isotopic ratios were expressed in terms of relative concentrations referred to a chitin standard, equivalent to Pee-Dee belemnite.

The diatom, pigments, sediment stable isotope and $\mathrm{C}: \mathrm{N}$ ratios data were analysed using a non-parametric multivariate analysis of variance (NPMANOVA, Anderson 2001) to test the null hypothesis that the periods before and after fish introduction would have differences in values, species composition and/or abundance of the different variables examined. The analysis was performed using the vegan package (Oksanen et al., 2016) under statistical software R version 3.2.0 (R Core Team, 2015).

\section{RESULTS}

\section{Nutrient mass balance model}

A total of 135 trout individuals (size range 16.0-39.7 $\mathrm{cm}$, mean total length $32.8 \pm 3.78 \mathrm{~cm} \mathrm{S.D.)} \mathrm{were} \mathrm{captured,}$ with a total biomass of $52.55 \mathrm{~kg}$ and a density of 78.44 $\mathrm{kg} \mathrm{ha}^{-1}$. These comprised trout hatched in 1997-2009 
which, before fish removal in 2009, were 0-12 years old. The regression parameters for the length/weight equation were estimated as $a=0.0045$ and $b=3.2443\left(R^{2}=0.82\right)$. Ageing using combined scales and otoliths indicated that three year-classes $(2000,2001,2002)$ constituted $79.25 \%$ of the population (whole range: 1997-2009) and no fish hatched in 2006 or 2007. Visual inspection of gonads indicated that trout were mature after 4 years of age, at a size of $29.4 \mathrm{~cm}$ and $272 \mathrm{~g}$ of weight, and that the sex ratio was equal. The SCA results underlined that aquatic arthropods were the most important food item for trout (56\% of the total prey volume, Tab. 1).

Based on the bioenergetic model for year 2009, annual nutrient load of fish derived nutrients was low, $0.72 \mathrm{~kg}$ and $0.13 \mathrm{~kg}$ for $\mathrm{N}$ and $\mathrm{P}$ respectively, relative to the external loads (Tab. 2). Annual external loads of $\mathrm{N}$ and $\mathrm{P}$ from the catchment area were estimated to be the biggest component, $151.8 \mathrm{~kg}$ and $5.8 \mathrm{~kg}$ respectively, whereas atmospheric loads of $\mathrm{N}$ and $\mathrm{P}(1.52 \mathrm{~kg}$ and $0.03 \mathrm{~kg}$ respectively) were more than one order of magnitude lower than that from the catchment area (Tab. 2). Therefore, internal P load due to fish presence $(2.2 \%$ of the total P load) represented a more important load component for $\mathrm{P}$ than the external load due to atmospheric deposition. Runoff from the catchment area dominated the $\mathrm{N}$ input (Tab. 2) and internally regenerated $\mathrm{N}$ from fish was a negligible component $(0.46 \%$ of the total $\mathrm{N}$ load).

The initial trout biomass used to model the population was $47.81 \mathrm{~kg}$ in 2009 . According to the model, after one year the total biomass of the population should have been $47.55 \mathrm{~kg}$, due to the effects of mortality. Without mortality, the biomass should have been $52.83 \mathrm{~kg}$, which was practically equivalent to the total biomass of $52.55 \mathrm{~kg}$ removed between 2010 and 2012.

Even if $2.6 \%$ of the fish wet mass is composed of $\mathrm{N}$ and $0.5 \%$ is composed of $\mathrm{P}$ (Tab. 1), the total amount of $\mathrm{N}$ and $\mathrm{P}$ sequestered in fish bodies during 2009 was 0 , due to the loss of biomass at the population level. Without accounting for mortality, only $0.13 \mathrm{~kg}$ of N and $0.02 \mathrm{~kg}$ of $\mathrm{P}$ would have been sequestered. Therefore, fish biomass could, in ideal conditions with no mortality, sequester only $18 \%$ and $15.2 \%$ of the $\mathrm{N}$ and $\mathrm{P}$ it regenerates. Overall, the

Tab. 2. Internal and external loads of $N$ and $P$ in Lake Kuutsjärvi on annual basis. Atmospheric deposition is expressed as mean and standard deviation.

\begin{tabular}{lcc} 
& $\mathrm{N}\left(\mathrm{kg} \mathrm{yr}^{-1}\right)$ & $\mathrm{P}\left(\mathrm{kg} \mathrm{yr}^{-1}\right)$ \\
Internal load & & \\
\hline Fish derived nutrients & 0.72 & 0.13 \\
\hline External load & & \\
Catchment area runoff & 151.8 & 5.8 \\
Atmospheric deposition & $1.52 \pm 0.26$ & $0.03 \pm 0.01$ \\
\hline
\end{tabular}

entire biomass of trout removed contained only $1.37 \mathrm{~kg}$ of $\mathrm{N}$ and $0.26 \mathrm{~kg}$ of $\mathrm{P}$; this is the total amount of nutrients sequestered by the whole population over a timespan of several years.

\section{Palaeolimnological analyses and nutrient model validation}

Seventy diatom taxa were enumerated from the subsamples. The diatom stratigraphy (Fig. 2) was divided by the constrained optimal sum of squares partitioning to zone into two statistically significant diatom assemblage zones (DAZ II and DAZ III) and one additional non-statistically significant diatom zone (DAZ I). DAZ I represents the 'reference' period dating back at least five hundred years (Korhola and Weckström 2004) and was dominated by the planktonic Aulacoseira subarctica and Asterionella formosa ( $20 \%)$. DAZ II covers the period prior to AD 1980, when trout were stocked in the lake. In this period, Aulacoseira subarctica still dominated the diatom community, whereas the relative abundance of $A s$ terionella formosa was significantly lower. At the end of this zone Aulacoseira subarctica started to slowly decrease, whereas Fragilaria pinnata (Staurosirella pinnata), a benthic diatom, increased. DAZ III represents the time after fish stocking (1980-present). This zone is characterized by a gradual decrease in the proportion of Aulacoseira subarctica from $\sim 60$ to $\sim 30 \%$ and a gradual increase of Staurosirella pinnata from $\sim 0$ to $\sim 25 \%$. The NPMANOVA also indicated a statistically significant change in diatom abundances after fish introduction $(\mathrm{P}=0.001$, pseudoF=7.0542, $\mathrm{df}=16)$.

The pigment assemblages indicated that siliceous algae were abundant in the lake and that cyanobacteria, chlorophytes and cryptophytes were also present (Fig. 3). The presence of the carotenoid okenone from anoxic photosynthetic bacteria (Fig. 3f) indicates both light penetration, consistent with the clear water conditions recorded (light penetration to the lake bottom at $8.5 \mathrm{~m}$ ), and oxygen depletion in the lake hypolimnion (McGowan et al., 2008). The NPMANOVA indicated that introduction of trout in 1980 had a significant impact on the composition or abundance of primary producers in the lake (NPMANOVA $\mathrm{P}=0.0243$, pseudoF $=4.3574, \mathrm{df}=15$ ), driven mostly by the increase in the cryptophyte pigment alloxanthin (Fig. 3d), after fish stocking.

The C:N ratio (mean 12.2) was typical of an aquatic system with some terrestrial linkages and showed moderate changes. Some shifts in stable isotope ratios occurred after fish introduction, including a shift towards lower $\delta^{13} \mathrm{C}$ and $\delta^{15} \mathrm{~N}$ values (Fig. 4 b,c) compatible with an increase in benthic primary production but not with an increase in terrestrial linkage. However, shifts in C:N ratio and $\delta^{13} \mathrm{C}$ and $\delta^{15} \mathrm{~N}$ values were not significant (NPMANOVA $\mathrm{P}=0.395$, pseu$\mathrm{doF}=0.9594, \mathrm{df}=15)$. 


\section{DISCUSSION}

The results of the nutrient load model, which did not predict a significant increase in bioavailable nutrients due to fish presence, were in accordance with palaeolimnological analysis, which indicated only few apparent changes in lake primary productivity corresponding with fish introduction.

\section{Is fish presence a significant element altering nutrient cycles in small boreal lakes?}

Our bioenergetic model suggests that nutrients derived from fish excretion were not an important component of the total load, even if fish-derived P load was higher than the atmospheric-derived P load. Catchment area load dominated the nutrient input even if nutrient loading from catchment runoff is probably overestimated in the model, because part of the catchment basin is located above the treeline and no catchment area load estimates were available for such landscapes (Kortelainen et al., 2006). As a result of this overestimation, fish excretion could be a more important nutrient source than estimated in our study. However, fish-derived nutrient load seems to be unlikely to have a relevant effect on nutrient dynamics of lake ecosystems, contrarily to previous evaluations (Hansson et al., 1987).

Terrestrial prey, in particular, contributed significantly to the trout diet in Lake Kuutsjärvi (31.5\% of the diet during the open water period, Tab. 1). This is an important factor, as it creates an additional flow of terrestrial nutrients into the system (Mehner et al., 2005; Cole et al., 2006; Milardi et al., 2016a). Trout simultaneously recycle aquatic nutrients and introduce nutrients derived from the terrestrial system, by preying on animals which would not otherwise enter the lake food web (e.g., swimming rodents, terrestrial flying insects). Thus, predation on terrestrial sources and subsequent excretion of terrestrial nutrients by introduced trout apparently increases terrestrial nutrient transport from the catchment to lakes. When fish die and decompose, these terrestrial nutrients are released in the aquatic system. This mechanism should further magnify the nutrient load to the lakes derived from fish presence, although the uptake of these sequestered nutrients is not always linear (Vanni et al., 2013). Similarly, fish egestion does not immediately affect nutrient

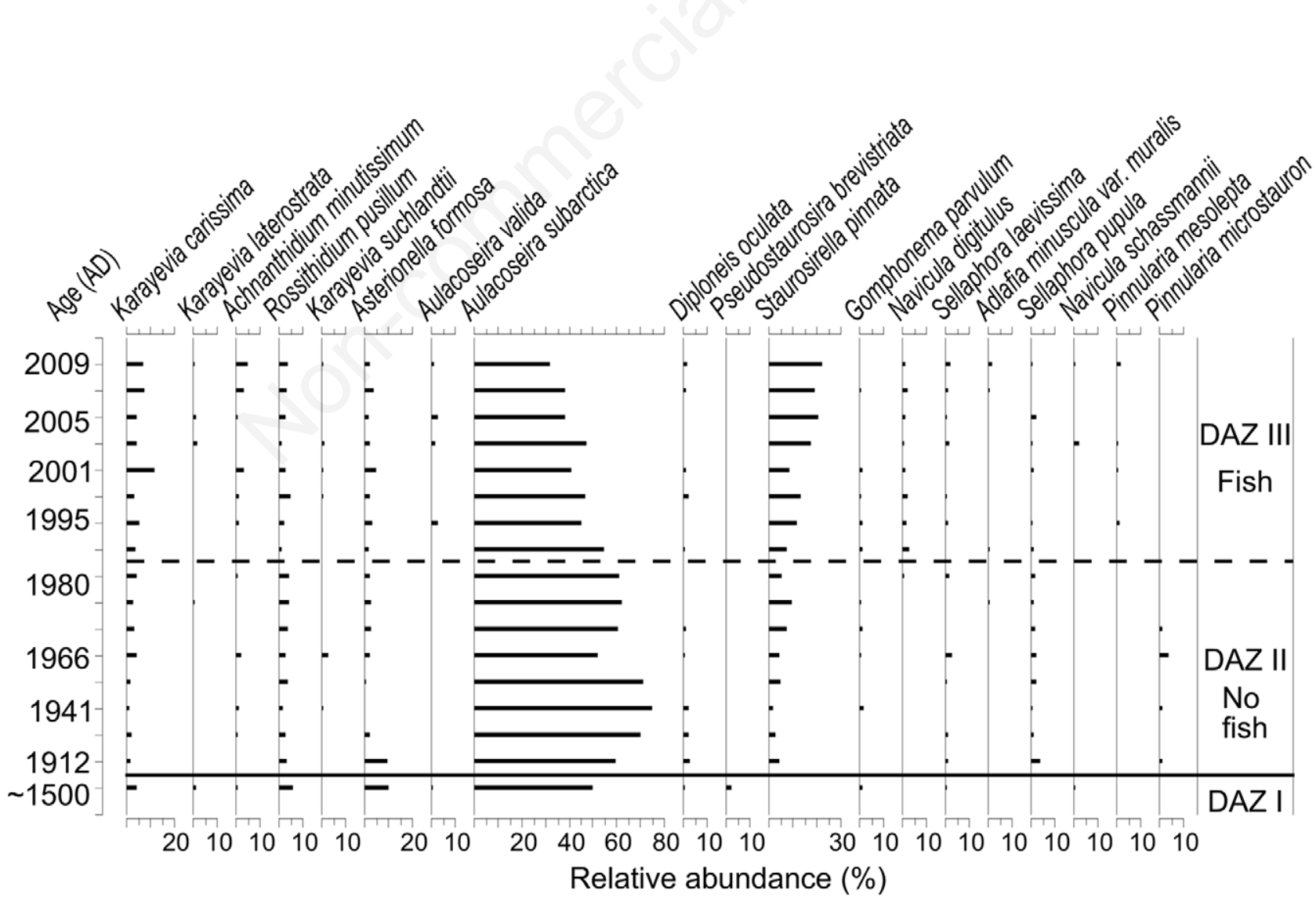

Fig. 2. Relative abundances of the most common diatom taxa from Lake Kuutsjärvi. A dashed line is used to separate statistically significant zones (DAZ II-III) and mark the year of fish introduction, whereas a continuous line is used to separate non-statistically significant zones (DAZ I). 

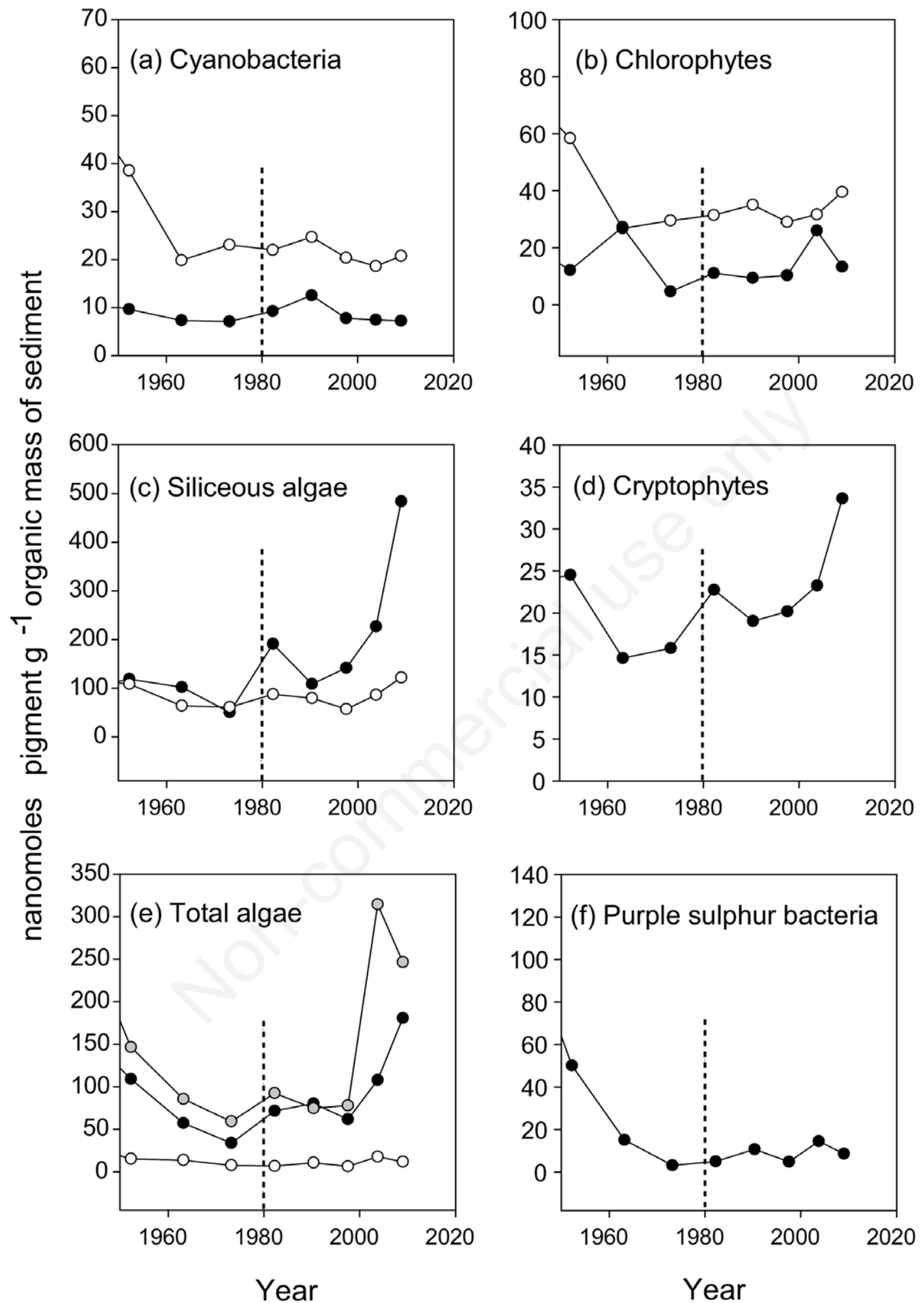

Fig. 3. Sedimentary pigment concentration in nanomoles per g organic mass of sediment from a) canthaxanthin (closed symbols) and zeaxanthin (open symbols) from cyanobacteria; b) ${ }^{*} \mathrm{Chl} \mathrm{b}$ (closed) and lutein (open); c) *fucoxanthin (closed) and diatoxanthin (open) from siliceous algae such as diatoms and chrysophytes (open); d) alloxanthin from crytophytes; e) *Chl a (closed), $\beta$-carotene (open) and pheophytin a (grey) produced by all algal groups; f) okenone from purple sulphur bacteria. Pigments that are degraded most easily are marked with an asterisk in the caption to indicate that increases in the upper sediments might be an artefact. The timing of fish introduction is marked with a vertical dashed line. 
dynamics of the lakes, as the portion of fish diet that is egested is, for the largest part, not readily available to primary producers without prior microbial breakdown (Brabrand et al., 1990; Vanni, 1996). However, eventually, egestion might stimulate the growth of bacterial decomposing organisms, and consequently enhance the growth of mixotrophic phytoplankton such as cryptophytes (Boros et al., 2014). As there are no estimations
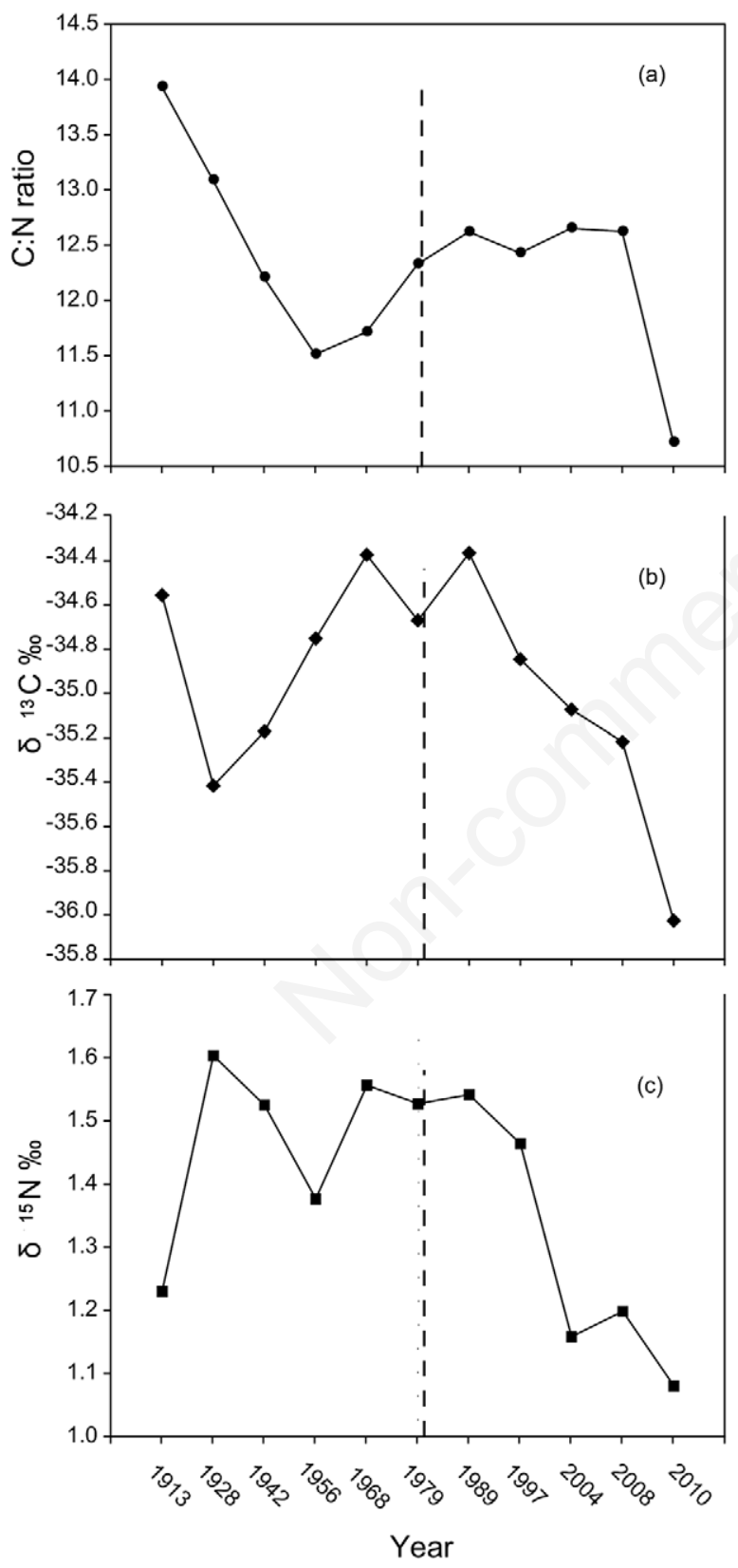

Fig. 4. Sediment atomic $\mathrm{C}: \mathrm{N}$ ratio (a), stable isotope ratios for $\mathrm{C}$ (b) and N (c) at different years. Dashed lines mark the year of fish introduction. on the timing and extent of such processes in Lake Kuutsjärvi, we focused on the most direct and immediate effects of fish predation derived from excretion, i.e. the cause of a fertilising effect on autotrophic production. However, egestion is a factor that likely plays a role in the overall nutrient load, as large numbers of aquatic and terrestrial organisms are killed by trout and then processed by decomposers.

The size-structure of the population is important when modelling the magnitude of nutrient cycling. Small-sized individuals feed on smaller prey at higher rates than largesized specimens (Tarvainen et al., 2005) but cycle nutrients at lower rates because of their higher allocations to somatic growth. However, the removal of trout showed that the population of Lake Kuutsjärvi in 2009 was rather peculiar and mainly composed of relatively large and slow-growing old individuals, with only few small and younger specimens. Larger trout individuals feed less on zooplankton and the results from SCA suggest that direct top-down control of fish on zooplankton, if any, was very limited. This could be of importance in our study lake because lower trophic levels typically have a higher biomass and therefore higher nutrient regeneration rates. While previous studies have noted that zooplankton might be more significant regenerators of $\mathrm{P}$ than fish (Sereda et al., 2008), our study could not account for such regeneration rates.

The amount of nutrients regenerated by the trout population in a single year, even if low, still exceeds the nutrients sequestered in fish bodies. Therefore, fish act as generators, rather than sinks, of nutrients. According to the model, there should be a positive net gain in bioavailable nutrients in the system due to fish presence, even if a very small one.

\section{Can the impact of fish introduction on the aquatic ecosystem be tracked in the sediment record?}

Fish introductions often lead to changes in food web structure and, due to their feeding ecology or habitat alteration, ultimately to trophic cascade effects (Carpenter et al., 1985). While young trout might partially feed on zooplankton, older trout feed mainly on the aquatic stages of terrestrial insects and on aquatic macro-invertebrates decreasing their abundance (Epanchin et al., 2010) which could relieve invertebrate predation pressure from small plankton grazers (Wilhelm and Schindler, 1999). This can result in more abundant grazer populations and increased grazing pressure on algal production (Milardi et al., 2016b).

High concentrations of diatom frustules and siliceous algal pigments suggest that diatoms are an important component of overall lake primary production. Based on diatom analysis, no inferred increase in pelagic nutrient concentration has occurred in Lake Kuutsjärvi during the last centuries, as the proportion of $A$. formosa was higher in the reference sample (from ca. 500 years ago) than 
today in the most recent sediments. This species is known to favour elevated nutrient concentrations, especially nitrogen (Lund, 1950; Krivtsov et al., 2000; Saros et al., 2005). The most evident change in the diatom stratigraphy occurs after the introduction of fish in 1980 (Fig. 2), with a decrease of the planktonic $A$. subarctica and the increase of the benthic $S$. pinnata. The increase of $S$. pinnata indicates a shift from planktonic to benthic primary production and also suggests a change from a relatively stable environment to an unstable, more turbulent/chaotic environment. Staurosirella (Fragilaria) species are often associated with high environmental instability and are known to tolerate broad environmental gradients (Haworth, 1976; Smol, 1988; Denys, 1990; Korhola, 1995). The timing of the gradual increase of $S$. pinnata during the last 34 years, following fish introduction, suggests that the main reason for the change in the diatom community was the introduction of fish. Diatom influx rates of Lake Kuutsjärvi are almost tenfold compared to e.g. Lake Nautajärvi, southern Finland (Weckström, unpublished data). Lake Kuutsjärvi has a very high sedimentary silica concentration compared to other boreal lakes (Tallberg et al., 2014), which might support a longer diatom bloom time and negate the effects of silica limitation. This is also supported by the occurrence of diatoms such as A. formosa and $A$. subarctica which bloom in the spring and favour waters with elevated silica concentration (Krivtsov et al., 2000; Horn et al., 2011).

Even if there was a significant change in pigments after fish introduction, pigment analysis did not reveal a clear change in lake trophic state, as Chlorophyll- $a$ and other pigment indicators (cyanobacteria, chlorophytes and purple sulphur bacteria) did not show significant trends that can be related to fish presence. The change was mainly related to diatom pigments, which showed an increase, but this may have been due to an increase in the abundance of benthic species, such as $S$. pinnata, and therefore a further confirmation of the switch to benthic production, which enhances pigment preservation in the sediment (Cuddington and Leavitt, 1999). The increase in alloxanthin could indicate an increase in bacterial production after fish introduction, which stimulated the growth of potentially mixotrophic cryptophytes ('the microbial loop'). Other pigments (fucoxanthin, $\mathrm{Chl} a$, pheophytin a) also increased over a decade after the stocking of trout but this may be caused by degradational changes in the upper sediments because fucoxanthin and $\mathrm{Chl} a$ are quite labile (McGowan, 2013); however the subsequent decline in Chl $a$ in the uppermost sample suggests that the patterns are not exclusively degradation-driven. It is also possible that fish stocking increased heterotrophic nutrient processing pathways by increasing the availability of organic matter through faeces and urine. Cryptophytes are capable of mixotrophy and so may have been able to di- rectly utilise these energy sources. Organic sources from fish wastes can serve as an energy source for heterotrophic bacteria which are grazed by smaller zooplankton and phagotrophic phytoplankton (Jansson et al., 2000). The presence of okenone indicating anoxia implies active decomposition of organic material in the deeper waters of the lake. However, okenone concentrations were low and did not rise significantly after fish introduction and there was a lag in the increase of alloxanthin, suggesting a rather subtle or indirect effect on lake microbial processing. It is possible that there was a cascading effect on algal communities through fish-induced changes in the food web structure (Strock et al., 2013). Consumption of aquatic arthropods in benthic and pelagic areas by fish might either enhance or depress algal production depending on whether prey items are primary (e.g., crustacean zooplankton, chironomidae) or secondary consumers (e.g., Odonata). However, this predation will fluctuate in time with variations in population structure, as different sized individuals focus on different prey. It is accepted, however, that trophic cascades exert more influence on lower trophic levels in oligotrophic lakes (McQueen et al., 1989), and so the rather high nutrient concentrations in the study lake may counter such effects. Chlorophyll$a$ concentrations suggest that algae have slightly increased overall; this is still likely affected by the increase in benthic primary producers.

Trout introduction effects were not significant in the $\mathrm{C}: \mathrm{N}$ ratio series, which remained stable over a long period of time and did not show the shift towards higher $\mathrm{C}: \mathrm{N}$ ratios, as predicted by the results of the nutrient mass balance model. The C:N ratio of Lake Kuutsjärvi sediments was typical of headwater lakes that have some linkage with the terrestrial system (Kortelainen et al., 2013). In Lake Kuutsjärvi, decreasing $\delta^{15} \mathrm{~N}$ and $\delta^{13} \mathrm{C}$ ratios, although not significant, could further indicate a production shift from pelagic to benthic habitats (as shown by diatom analysis) but could also be the result of an increase in primary production of diatoms (Hundey et al., 2014). Taking into account the pigment trends and the accumulation rates of diatoms (Weckström, unpublished data), which do not show any significant trend, it is unlikely that a production increase has actually occurred. Previous studies noted that $\delta^{15} \mathrm{~N}$ ratios should increase $3-4 \%$ in lakes where fish populations have cascading effects on phytoplankton production, as increased phytoplankton biomass usually produces higher values of $\delta^{15} \mathrm{~N}$ due to a preferential utilization of ${ }^{15} \mathrm{~N}$ (Gąsiorowski and Sienkiewicz, 2013). Furthermore, increased phytoplankton biomass often decreases $\delta^{13} \mathrm{C}$ ratios in sediments, due to the preferential utilization of ${ }^{12} \mathrm{C}$ (France, 1995). On the contrary, increases in phytobentos biomass have been associated with increases in $\delta^{13} \mathrm{C}$ as benthic algae have higher $\delta^{13} \mathrm{C}$ ratios than planktonic ones (France, 1995; 
Wang et al., 2013). Together, the stable $\mathrm{C}: \mathrm{N}$ ratios and the slight decrease in $\delta^{15} \mathrm{~N}$ and $\delta^{13} \mathrm{C}$ ratios could suggest that benthic production after fish introduction did not increase significantly and that trouts could have slightly increased the linkage with the terrestrial system, which is ${ }^{13} \mathrm{C}$ depleted.

In conclusion, most palaeolimnological proxies used in this study coherently suggested that there was a shift from planktic to benthic primary production. However, the palaeolimnological proxies confirmed the prediction of the nutrient mass balance model that bioavailable nutrients in the lake did not significantly increase after fish introduction. The water retention time (under 2 months) could be short enough to rapidly cycle lake water flushing some of the nutrients regenerated by trout out of the system before they are uptaken by planktic and benthic micro-organisms (Kozerski et al., 1999, Köhler et al., 2005). Macro-organisms, on the other hand, would be reduced by trout predation, therefore potentially reducing the animal-derived overall nutrient regeneration rates (Vanni, 2002). Moreover, as the lake receives groundwater input through bottom springs, there might have been switches between closed and open basin hydrology. Also climate changes could influence the effects of nutrient loading, if these shorten the open water period, and affect the water mixing dynamics (Douglas and Smol, 2000). However, average summer air temperatures, precipitation and the ice cover period have all remained fairly stable in the past 25 years (Milardi et al., 2016b), suggesting that these might not explain the changes seen in the lake. Finally, the model estimates are valid for a limited 'snapshot' of time, as the complete history of the trout population dynamics is unknown. Although wide fluctuations in the trout population structure are unlikely over a short time span (ca. 5 years, Platts and Nelson, 1988), they could have been significant over the 34 years since introduction, thus influencing the overall effect.

\section{CONCLUSIONS}

Our study suggests that Lake Kuutsjärvi has not significantly increased its production but might have increased slightly its dependency upon terrestrial C. However, there is strong evidence for a shift from planktonic to benthic algal production after fish introduction, suggesting that introduced fish enhanced nutrient transport to the bottom of the lake, most likely through the production and sinking of wastes. Subtle increases in mixotrophic algae could suggest changes in microbial/ bacterial processing. These, coupled with $\mathrm{C}: \mathrm{N}$ ratios and $\delta^{13} \mathrm{C}$ trends, could be an indication of a subtle increase in the terrestrial energy pathway to the lake.

Further studies would be needed to explore the relation between fish introduction and nutrient balance on a wider range of high-latitude lakes, using different models and different species to test their validity. However, future studies will face a major challenge in selecting study systems where a sufficient level of historical information (e.g., date of fish introduction) is available.

\section{ACKNOWLEDGEMENTS}

The authors would like to thank Daniel Schindler for his help with the bioenergetic and nutrient modeling. We would also like to thank Petri Ekholm and Jussi Vuorenmaa at the Finnish Environmental Centre for their help with catchment area load and for providing the P deposition rates, respectively. We would also like to acknowledge the Värriö Research Station personnel for helping with field sampling, the Finnish Meteorological Institute for providing $\mathrm{N}$ atmospheric deposition data, Mari Kovero for providing additional information on diatoms and three anonymous reviewers for their useful comments to the paper. This project was started by Anne Liljendahl and funded by the Maj and Tor Nessling Foundation and the Academy of Finland (FICCA-program, Cliche Consortium).

\section{REFERENCES}

Ahtiainen M, Huttunen P, 1999. Long-term effects of forestry managements on water quality and loading in brooks. Boreal Environ. Res. 4:101-114.

Anderson MJ, 2001. A new method for non-parametric multivariate analysis of variance. Austral. Ecol. 26:32-46.

Appleby P, Oldfield F, 1978. The calculation of lead-210 dates assuming a constant rate of supply of unsupported $210 \mathrm{~Pb}$ to the sediment. Catena 5:1-8.

Bagenal TB, Tesch FW, 1971. Methods for assessment of fish production in fresh waters. Blackwell Scientific Publications Oxford.

Battarbee RW, 1986. Diatom analysis. In Berglund BE (ed), Handbook of Holocene palaeoecology and palaeohydrology. John Wiley, Chichester. pp 527-570.

Battarbee RW, 2000. Palaeolimnological approaches to climate change, with special regard to the biological record. Quaternary Sci. Rev. 19:107-124.

Bennett KD, 1996. Determination of the number of zones in a biostratigraphical sequence. New Phytol. 132:155-170.

Birks HJB, Gordon AD, 1985. Numerical methods in Quaternary pollen analysis. Academic Press: 317 pp.

Bøhn T, Amundsen P, 2001. The competitive edge of an invading specialist. Ecology 82:2150-2163.

Boros G, Takács P, Vanni MJ, 2014. The fate of phosphorus in decomposing fish carcasses: a mesocosm experiment. Freshwater Biol. 60:479-489.

Brabrand Å, Faafeng BA, Moritz Nilssen JP, 1990. Relative importance of phosphorus supply to phytoplankton production: fish excretion versus external loading. Can. J. Fish. Aquat. Sci. 47:364-372. 
Carpenter S, Cole J, Pace M, Batt R, Brock W, Cline T, Coloso J, Hodgson J, Kitchell JF, Seekell DA, Smith L, Weidel B, 2011. Early Warnings of Regime Shifts: A Whole-Ecosystem Experiment. Science 332:1079-1082.

Carpenter S, Kitchell JF, Hodgson JR, 1985. Cascading trophic interactions and lake productivity. Bioscience 35:634-639.

Chen N, Bianchi TS, McKee BA, Bland JM, 2001. Historical trends of hypoxia on the Louisiana shelf: application of pigments as biomarkers. Org. Geochem. 32:543-561.

Cole JJ, Carpenter SR, Pace M, Van De Bogert MC, Kitchell J, Hodgson JR, 2006. Differential support of lake food webs by three types of terrestrial organic carbon. Ecol. Lett. 9:558-568.

Cuddington K, Leavitt P, 1999. An individual-based model of pigment flux in lakes: Implications for organic biogeochemistry and paleoecology. Can. J. Fish. Aquat. Sci. 56:1964-1977.

Cummins KW, Wuycheck JC, 1971. Caloric equivalents for investigations in ecological energetics. International association of theoretical and applied limnology. E. Schweizerbart, Stuttgart: $158 \mathrm{pp}$.

Denys L, 1990. Fragilaria blooms in the Holocene of the western coastal plain of Belgia, p. 397-406. Proceedings $10^{\text {th }}$ International Diatom Symposium, Joensuu, Finland.

Dibble ED, Kovalenko K, 2009. Ecological impact of grass carp: a review of the available data. J. Aquat. Pl. Manag. 47:1-15.

Dierenfeld ES, Alcorn HL, Jacobsen KL, 2002. Nutrient composition of whole vertebrate prey (excluding fish) fed in zoos. US Department of Agriculture, Agricultural Research Service, National Agricultural Library, Animal Welfare Information Center.

Dieterman DJ, Thorn WC, Anderson CS, 2004. Application of a bioenergetic model for brown trout to evaluate growth in southeast Minnesota streams. Minnesota Department of Natural Resources, Section of Fisheries 513.

Douglas MS, Smol JP, 2000. Eutrophication and recovery in the high arctic: Meretta Lake (Cornwallis Island, Nunavut, Canada) revisited. Hydrobiologia 431:193-204.

Duffy JE, Cardinale BJ, France KE, McIntyre PB, Thébault E, Loreau M, 2007. The functional role of biodiversity in ecosystems: incorporating trophic complexity. Ecol. Lett. 10:522-538.

Dunne JA, Williams RJ, Martinez ND, 2002. Network structure and biodiversity loss in food webs: robustness increases with connectance. Ecol. Lett. 5:558-567.

Elser JJ, Fagan WF, Denno RF, Dobberfuhl DR, Folarin A, Huberty A, Interlandi S, Kilham SS, McCauley E, Schulz KL, 2000. Nutritional constraints in terrestrial and freshwater food webs. Nature 408:578-580.

Epanchin PN, Knapp RA, Lawler SP, 2010. Nonnative trout impact an alpine-nesting bird by altering aquatic-insect subsidies. Ecology 91:2406-2415.

Folke C, Carpenter S, Walker B, Scheffer M, Elmqvist T, Gunderson L, Holling C, 2004. Regime shifts, resilience, and biodiversity in ecosystem management. Annu. Rev. Ecol. Evol. S. 35:557-581.

France RL, 1995. Carbon-13 enrichment in benthic compared to planktonic algae: foodweb implications. Mar. Ecol. Prog. Ser. 124:307-312.

García-Berthou E, Alcaraz C, Pou-Rovira Q, Zamora L, Coenders G, Feo C, 2005. Introduction pathways and establish- ment rates of invasive aquatic species in Europe. Can. J. Fish. Aquat. Sci. 62:453-463.

Gąsiorowski M, Sienkiewicz E, 2013. The Sources of Carbon and Nitrogen in Mountain Lakes and the Role of Human Activity in Their Modification Determined by Tracking Stable Isotope Composition. Water Air Soil Poll. 224:1-9.

Hanson P, Johnson T, Schindler D, Kitchell J, 1997. Fish bioenergetics 3.0 software and manual. Sea Grant Institute. Center for Limnology, University of Wisconsin-Madison.

Hansson L, Johansson L, Persson L, 1987. Effects of fish grazing on nutrient release and succession of primary producers. Limnol. Oceanogr. 32:723-729.

Haworth EY, 1976. Two late-glacial (Late Devensian) diatom assemblage profiles from northern Scotland. New Phytol. 77:227-256

Hayden B, Holopainen T, Amundsen P, Eloranta AP, Knudsen R, Praebel K, Kahilainen KK, 2013. Interactions between invading benthivorous fish and native whitefish in subarctic lakes. Freshwater Biol. 58:1234-1250.

Heiri O, Lotter AF, Lemcke G, 2001. Loss on ignition as a method for estimating organic and carbonate content in sediments: reproducibility and comparability of results. J. Paleolimnol. 25:101-110.

Horn H, Paul L, Horn W, Petzoldt T, 2011. Long-term trends in the diatom composition of the spring bloom of a German reservoir: is Aulacoseira subarctica favoured by warm winters? Freshwater Biol. 56:2483-2499.

Hundey E, Moser K, Longstaffe F, Michelutti N, Hladyniuk R, 2014. Recent changes in production in oligotrophic Uinta Mountain lakes, Utah, identified using paleolimnology. Limnol. Oceanogr. 59:1987-2001.

Jansson M, Bergström A, Blomqvist P, Drakare S, 2000. Allochthonous organic carbon and phytoplankton/bacterioplankton production relationships in lakes. Ecology 81: 3250-3255.

Jonsson N, Jonsson B, 1999. Trade-off between egg mass and egg number in brown trout. J. Fish Biol. 55:767-783.

Jonsson B, Jonsson N, 2011. Ecology of Atlantic Salmon and Brown Trout-Habitat as a Template for Life Histories. Springer, London.

Juggins S, 2007. C2 Version 1.5: software for ecological and palaeoecological data analysis and visualisation. University of Newcastle, Newcastle upon Tyne.

Kernan MR, Battarbee RW, Moss B, 2010. Climate change impacts on freshwater ecosystems. Wiley Online Library.

Kitchell JF, Stewart DJ, Weininger D, 1977. Applications of a bioenergetics model to yellow perch (Perca flavescens) and walleye (Stizostedion vitreum vitreum). J. Fish. Res. Board Can. 34:1922-1935.

Köhler J, Hilt S, Adrian R, Nicklisch A, Kozerski H, Walz N, 2005. Long-term response of a shallow, moderately flushed lake to reduced external phosphorus and nitrogen loading. Freshwater Biol. 50:1639-1650.

Korhola A, 1995. The Litorina transgression in the Helsinki region, southern Finland: new evidence from coastal mire deposits. Boreas 24:173-182.

Korhola A, Weckström J, 2004. Paleolimnological studies in arctic Fennoscandia and the Kola Peninsula (Russia). In: Pienitz R, Douglas MSV, Smol JP (eds.) Long-term environmental change in Arctic and Antarctic lakes. Springer. pp 381-418. 
Kortelainen P, Rantakari M, Pajunen H, Huttunen JT, Mattsson T, Juutinen S, Larmola T, Alm J, Silvola J, Martikainen PJ, 2013. Carbon evasion/accumulation ratio in boreal lakes is linked to nitrogen. Global Biogeochem. Cy. 27:363-374.

Kortelainen P, Mattsson T, Finér L, Ahtiainen M, Saukkonen S, Sallantaus T, 2006. Controls on the export of C, N, P and Fe from undisturbed boreal catchments, Finland. Aquat. Sci. 68:453-468.

Kozerski H, Behrendt H, Köhler J, 1999. The N and P budget of the shallow, flushed lake Müggelsee: retention, external and internal load. Hydrobiologia 408/409:159-166.

Kraft CE, 1992. Estimates of phosphorus and nitrogen cycling by fish using a bioenergetics approach. Can. J. Fish. Aquat. Sci. 49:2596-2604.

Krammer K, Lange-Bertalot H, 1986. [Süsswasserflora von Mitteleuropa. Bacillariophyceae. 1. Teil: Naviculaceae, vol 2/1].[Book in German]. G. Fischer Verlag, Jena.

Krammer K, Lange-Bertalot H, 1988. [Bacillariophyceae 2. Bacillariaceae, Epithemiaceae, Surirellaceae 2/2. Süsswasserflora vom Mitteleuropa].[Book in German]. G. Fischer Verlag, Jena.

Krammer K, Lange-Bertalot H, 1991. [Bacillariophyceae 4. Teil: Achnanthaceae, Kritische Erganzungen zu Navicula (Lineolate) und Gomphonema Gesammliteratur-verzeichnis].[Book in German] G. Fischer Verlag, Jena.

Krammer K, Lange-Bertalot H, 1991. Bacillariophyceae. 3. Teil: Centrales, Fragilariaceae, Eunotiaceae. Süßwasserflora von Mitteleuropa. 2/3. Ettl, Gerloff, Heynig and Mollenhauer, Eds). G.Fischer Verlag, Jena.

Krivtsov V, Bellinger E, Sigee D, 2000. Changes in the elemental composition of Asterionella formosa during the diatom spring bloom. J. Plankton Res. 22:169-184.

Lall S, 1991. Digestibility, metabolism and excretion of dietary phosphorus in fish, p. 21-36. In: C.B. Cowey and C.Y. Cho (eds.), Nutritional strategies and aquaculture waste. University of Guelph Library, Guelph.

Leavitt PR, Hodgson DA, 2001. Sedimentary pigments, p 295325. In: J.P. Smol, H.J.B. Birks and W.M. Last (eds.) Tracking environmental change using lake sediments 3: Terrestrial, algal, and siliceous indicators. Kluwer Academic Publishers, Dordrecht.

Leavitt P, Schindler D, Paul A, Hardie A, Schindler D, 1994. Fossil pigment records of phytoplankton in trout-stocked alpine lakes. Can. J. Fish. Aquat. Sci. 51:2411-2423.

Lotter A, Juggins S, 1991. POLPROF, TRAN and ZONE: programs for plotting, editing and zoning pollen and diatom data. INQUA-Subcommission for the study of the Holocene Working Group on Data-Handling Methods. Newsletter 6:4-6.

Lund J, 1950. Studies on Asterionella formosa hass: II. Nutrient depletion and the spring maximum. J. Ecol. 38:15-35.

McGowan S, 2013. Pigment studies, p. 326-328. In: E. Scott (ed.), The encyclopedia of quaternary science. Elsevier, Amsterdam.

McGowan S, Juhler RK, Anderson NJ, 2008. Autotrophic response to lake age, conductivity and temperature in two West Greenland lakes. J. Paleolimnol. 39:301-317.

McLauchlan KK, Williams JJ, Engstrom DR, 2013. Nutrient cycling in the palaeorecord: Fluxes from terrestrial to aquatic ecosystems. The Holocene 23:1635-1643.

McQueen DJ, Johannes MR, Post JR, Stewart TJ, Lean DR, 1989. Bottom-up and top-down impacts on freshwater pelagic community structure. Ecol. Monogr. 59:289-309.

Mehner T, Ihlau J, Dörner H, Hölker F, 2005. Can feeding of fish on terrestrial insects subsidize the nutrient pool of lakes? Limnol. Oceanogr. 50:2022-2031.

Milardi M, Käkelä R, Weckström J, Kahilainen KK, 2016a Terrestrial prey fuels the fish population of a small, high-latitude lake. Aquat. Sci. 78:695-706.

Milardi M, Siitonen S, Lappalainen J, Liljendahl A, Weckström J, 2016b. The impact of trout introductions on macro- and micro-invertebrate communities of fishless boreal lakes. J. Paleolimnol. 55:273-287.

Moss B, McKee D, Atkinson D, Collings S, Eaton J, Gill A, Harvey I, Hatton K, Heyes T, Wilson D, 2003. How important is climate? Effects of warming, nutrient addition and fish on phytoplankton in shallow lake microcosms. J. Appl. Ecol. 40:782-792.

Nakashima BS, Leggett WC, 1980. The role of fishes in the regulation of phosphorus availability in lakes. Can. J. Fish. Aquat. Sci. 37:1540-1549.

Oksanen J, Blanchet FG, Kindt R, Legendre P, Minchin PR, O'Hara RB, Simpson GL, Solymos P, Stevens MHH, Wagner H, 2016. Package vegan. Community Ecology Package (version 2.3-3).

Pace ML, Cole JJ, Carpenter SR, Kitchell JF, 1999. Trophic cascades revealed in diverse ecosystems. Trends Ecol. Evol. 14:483-488.

Pace M, Cole JJ, Carpenter SR, Kitchell JF, Hodgson, Van de Bogert MC, Bade DL, Kritzberg ES, Bastviken D, 2004. Whole-lake carbon-13 additions reveal terrestrial support of aquatic food webs. Nature 427:240-243.

Penczak T, Molinski M, Galicka W, Prejs A, 1985. Factors affecting nutrient budget in lakes of the R. Jorka watershed (Masurian Lakeland, Poland). VII. Input and removal of nutrients with fish. Ekol. Pol. 33:301-309.

Platts WS, Nelson RL, 1988. Fluctuations in trout populations and their implications for land-use evaluation. N. Am. J. Fish. Manage. 8:333-345.

R Core Team, 2015. R: A Language and Environment for Statistical Computing. R Foundation for Statistical Computing, Vienna, Austria.

Renberg I, Hansson H, 2008. The HTH sediment corer. J. Paleolimnol. 40:655-659.

Saros JE, Michel TJ, Interlandi SJ, Wolfe AP, 2005. Resource requirements of Asterionella formosa and Fragilaria crotonensis in oligotrophic alpine lakes: implications for recent phytoplankton community reorganizations. Can. J. Fish. Aquat. Sci. 62:1681-9.

Schindler DE, Eby LA, 1997. Stoichiometry of fishes and their prey: Implications for nutrient recycling. Ecology 78: 1816-1831.

Schindler DE, Knapp RA, Leavitt PR, 2001. Alteration of nutrient cycles and algal production resulting from fish introductions into Mountain Lakes. Ecosystems 4:308-321.

Sereda JM, Hudson JJ, Taylor WD, Demers E, 2008. Fish as sources and sinks of nutrients in lakes. Freshwater Biol. 53:278-289.

Smol JP, 1988. Paleoclimate proxy data from freshwater arctic diatoms. Verh. Int. Ver. Limnol. 23:837-844.

Strock KE, Saros JE, Simon KS, McGowan S, Kinnison MT, 2013. Cascading effects of generalist fish introduction in oligotrophic lakes. Hydrobiologia 711:99-113. 
Tallberg P, Opfergelt S, Cornelis J, Liljendahl A, Weckström J, 2014. High concentrations of amorphous, biogenic Si (BSi) in the sediment of a small high-latitude lake: implications for biogeochemical Si cycling and for the use of BSi as a paleoproxy. Aquat. Sci. 77:1-13.

Tammi J, Appelberg M, Beier U, Hesthagen T, Lappalainen A, Rask M, 2003. Fish status survey of Nordic lakes: effects of acidification, eutrophication and stocking activity on present fish species composition. Ambio 32:98-105.

Tarvainen M, Ventela A, Helminen H, Sarvala J, 2005. Nutrient release and resuspension generated by ruffe (Gymnocephalus cernuus) and chironomids. Freshwater Biol. 50:447-458.

Thaulow J, Haugen TO, Borgstrøm R, 2017. Parallelism in thermal growth response in otoliths and scales of brown trout (Salmo trutta L.) from alpine lakes independent of genetic background. Ecol. Freshw. Fish. 26: 53-65.

Thornton KW, Lessem AS, 1978. A temperature algorithm for modifying biological rates. Trans. Am. Fish. Soc. 107:284-287.

Vanni MJ, 1996. Nutrient transport and recycling by consumers in lake food webs: implications for algal communities, p. 8195. In: G.A. Polis and K.O. Winemiller (eds.), Food webs. Integration of patterns \& dynamics. Springer, Dordrecht.

Vanni MJ, Renwick WH, González MH, 2013. Nutrient and sediment concentrations in three agriculturally impacted streams over a 15-year period: ecological archives E094085. Ecology 94:978-978.

Vanni MJ, 2002. Nutrient cycling by animals in freshwater ecosystems. Annu. Rev. Ecol. Evol. 33:341-370.

Wang L, Mackay AW, Leng MJ, Rioual P, Panizzo VN, Lu H, Gu Z, Chu G, Han J, Kendrick JP, 2013. Influence of the ratio of planktonic to benthic diatoms on lacustrine organic matter $\delta 13 \mathrm{C}$ from Erlongwan maar lake, northeast China. Org. Geochem. 54:62-68.

Weber MJ, Brown ML, 2009. Effects of common carp on aquatic ecosystems 80 years after "carp as a dominant": ecological insights for fisheries management. Rev. Fish. Sci. 17:524-537.

Weckström J, Korhola A, Blom T, 1997. The relationship between diatoms and water temperature in thirty subarctic Fennoscandian lakes. Arctic and Alpine Res. 29:75-92.

Wilhelm FM, Schindler DW, 1999. Effects of Gammarus lacustris (Crustacea: Amphipoda) on plankton community structure in an alpine lake. Can. J. Fish. Aquat. Sci. 56:1401-1408.

Windell J, 1971. Food analysis and rate of digestion, p. 215-226. In: T.B. Bagenal and F.W. Tesch (eds.), Methods for assessment of fish production in fresh waters. Blackwell Scientific Publications, Oxford. 